ISAHP Article: Mu, Saaty/A Style Guide for Paper Proposals To Be Submitted to the International Symposium of the Analytic Hierarchy Process 2014, Washington D.C., U.S.A.

\title{
DETERMINATION THE SIGNIFICANCE LEVEL OF FACTORS THAT ARE AFFECTING YOUNG CONSUMERS' PURCHASING PREFERENCES BY AHP
}

\author{
Mustafa Hotamışlı \\ Faculty of Economics and Administrative Sciences \\ Afyon Kocatepe University \\ Afyon, TURKEY \\ E-mail: hotamisli@aku.edu.tr \\ Müfit Aydın \\ Faculty of Economics and Administrative Sciences \\ Uşak University \\ Uşak, TURKEY \\ E-mail: mufit.aydin@usak.edu.tr \\ M.Yasir Altıntop \\ Ahmetli Vocational High School \\ Celal Bayar University \\ Ahmetli,Manisa, TURKEY \\ E-mail: yasir.altintop@cbu.edu.tr
}

\begin{abstract}
The purpose of the study is to determine the significance level of factors that are affecting young consumers' purchasing preferences by AHP. In this point of view, primarily criteria that are effective in the purchasing preferences of young consumers' are defined as brand, price, quality, color and design, advertising, availability, promotions and discounts, conformity to fashion and after-sales services. These criteria will be applied separately to each essential product group such as food \& beverage, clothing \& accessories and technological products. Obtained results will be revealed in the full paper.
\end{abstract}

Keywords: Purchasing Decision Making, Consumer Preferences, AHP 


\section{Introduction}

For businesses to predict consumer's preferences and behaviors and to prepare marketing plan according to them has been always challenging process. Nowadays, businesses are faced with more diverse target group which has most choice ever. One of the most important of these are young consumers. This fact reveals that young consumers' buying behavior needs to be analyzed better.

Modern marketing requires to achieve customer loyalty by performing at the highest level of customer satisfaction. For that reason, it has been crucial to have effective market research which contains the high level of satisfaction, a strong loyalty relationship, well research on young consumers' preferences and factors affecting them.

\section{Literature Review}

Although there has been recent studies on the factors affecting young consumers' buying preferences, in literature review there hasn't been encountered a study that was analyzed by Analytic Hierarchy Process (AHP) about young consumers' buying preferences. In the study of Comert and Durmaz (2006), when young consumers are purchasing a product or service; eligibility of the product or service with his/her age (\%91), personal preference to product or service $(\% 89)$, his/her economic status (88), product or service compatibility to his/her culture, beliefs and traditions (\%88), ease of finding replacement parts $(\% 82)$, warranty period $(\% 80)$, in accordance with his/her profession (\%78), color and the design of product $(\% 75)$, a presence of usage tarif $(\% 73)$, family's opinion about product $(\% 70)$, price of the product $(\% 70)$, the store image $(\% 65)$, the brand of product or service (\%63) were indicated as an influential factors. Meanwhile, approximately half of the respondents stated that quality of product or service, giving gifts on besides the product and convincing ability of seller are influential factors as well. Yet, they stated that fashion, friends' opinion, commercials and samle group are not influential factor on their buying preference.

In another study (Çakır vd., 2010), it was stated that for college students food expenditure $(\% 15)$,and clothing expenditure (\%14) are prominent factors. In addition; it is stated that the color of product has also significant effect on purchasing behaviour. In the study it is determined a significance difference on factors affecting a product preferences.

Prominent factors as a determinants on product preference are as follows: country/city of production $(\% 11,63)$, the appearance of store $(\% 10,43)$ and commercial of product $(10,28)$.

In the study of Firat vd., (2014), it was carried out to obtain factors affecting the choice of beverage products for households in their süpermarket shopping. Factors were listed as; the taste of beverage, brand loyalty and given gifts and promotions. 


\section{Hypotheses/Objectives}

The purpose of the study is to determine the significance level of factors that are affecting young consumers' purchasing preferences by AHP. In this direction; hypothesis are determined as follows:

1. There is a difference in significance level of factors affecting the young consumers' purchasing behavior.

2. Significance level of factors affecting the young consumers' purchasing behavior are differentiated according to product groups..

\section{Research Design/Methodology}

To determine the significance level of factors that are effecting young consumers' purchasing preferences by AHP the following research design has been created.

In order to obtain the essential product groups and factors affecting the young consumers' purchasing preferences, a brainstorming method with a group of seven young people were applied. By the result of brainstorming method the following 3 product groups were determined:

1. Food and Beverages

2. Clothing and Accessories

3. Technological products

Additionally, the same group of people determined product features, which are the criteria of our study and have influence on purchasing preference. Product features were determined as followings; brand, price, quality, color and design, commercial, accessibility, promotions and discounts, fashionableness and after sales services.

Due to determine the significance level of criteria and to analyze them by AHP, the sample will consist of young consumers between the ages of 16-24 according to data from the Statistics Institute of Turkey. Therefore, pairwise comparison based questionnaire were distributed and applied to freshman and sophomore students in business administration faculty of Uşak University.

In questionnaire structure, to determine the alternative priorities and the weights of criteria, 1-9 rating scale that is proposed by Saaty was used. In this case, the sample were attained which contains 36 comparison for each group and in total 108 comparison for 3 groups.

\section{Data/Model Analysis}

In the figure below hierarchical structure of the problem on the determination of the significance level of factors that are affecting young consumers' purchasing preferences by AHP is shown. 


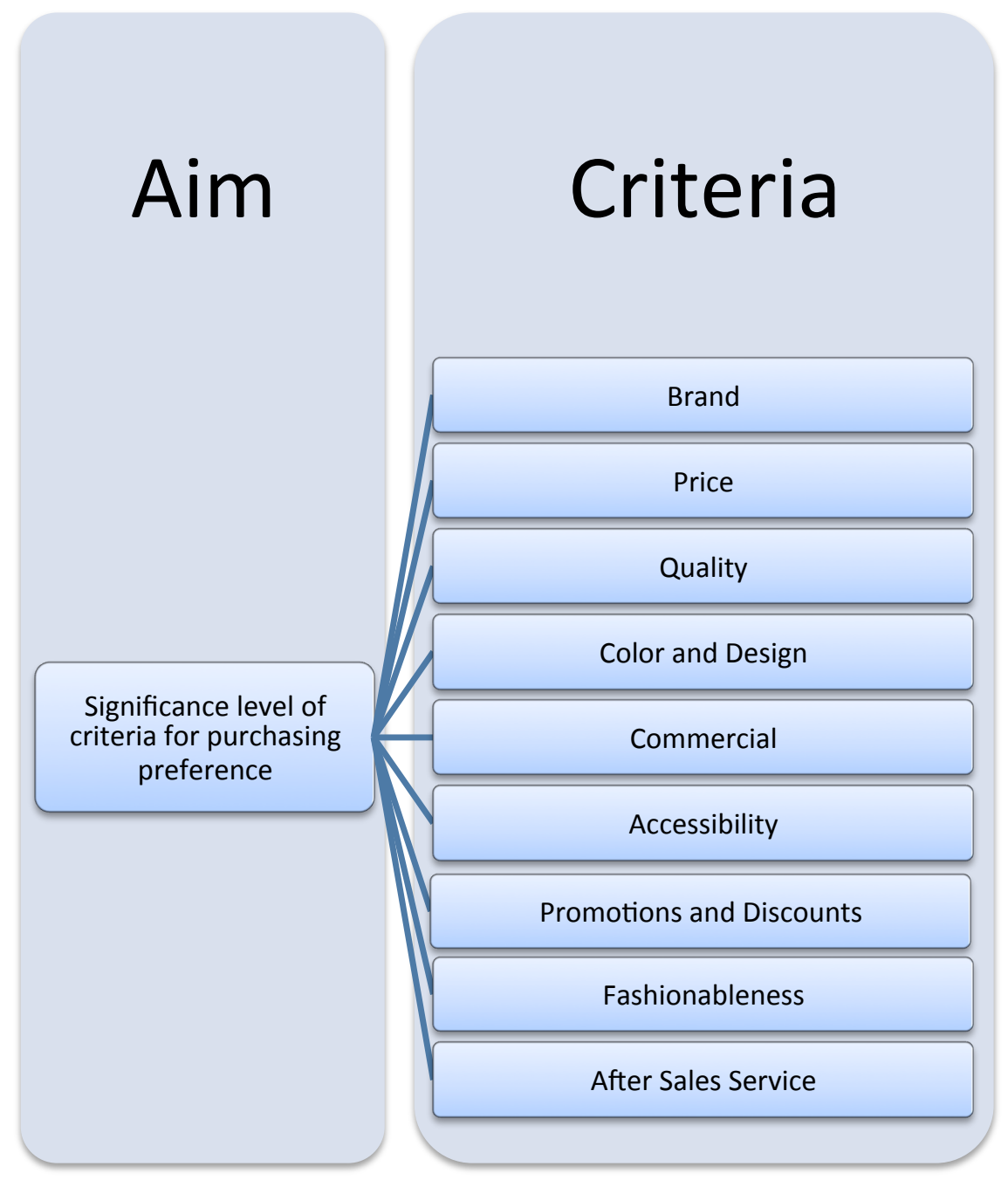

Figure 1: Hierarchical structure of the problem on the determination of the significance level of factors that are affecting young consumers' purchasing preferences by AHP

\section{Limitations}

All results will be achieved in this study are limited with the views of young people in the survey sample attained, product groups and features used in the study. For the future studies, it is recommended to have larger sample group and more product groups.

\section{Conclusions}

This study is a research on the application of AHP technique. Upon the completion of all process in the research, it is expected that the obtained results will be lodestar for marketers. In the age of technology and communication, where the businesses have to acquaint more closely the behaviors and needs of their customers, to get information and 
IJAHP Article: Mu, Saaty/A Style Guide for Paper Proposals To Be Submitted to the International Symposium of the Analytic Hierarchy Process 2014, Washington D.C., U.S.A.

to make realistic predictions as well as in the stage of developing successful strategies to increase their competitiveness, it is believed that the obtained results will be a crucial as a source of data for managers.

\section{Key References}

Saaty TL, Vargas LG (2001) Models, Methods, Concepts and Applications of the Analytic Hierarchy Process. Kluwer, Dordrecht.

Saaty, T.L. (2008). Decision making with the analytic hierarchy process. International Journal Services Sciences, 1(1), 83-98.

Yavuz, C. \& Yakup, D. (2006). Tüketicinin Tatmini İle Satın Alma Davranışlarını Etkileyen Faktörlere Bütünleşik Yaklaşım Ve Adıyaman İlinde Bir Alan Çalışması Journal Of Yasar University,1(4), 351-375.

Mesut, Ç., Fatma, Ç., \& Gülşah, U. (2010). Üniversite Öğrencilerinin Tüketim Tercihlerini Etkileyen Faktörlerin Belirlenmesi Organizasyon Ve Yönetim Bilimleri Dergisi Cilt 2, Sayi 2. Issn: 1309 -8039 (Online).

Aytekin, F., Atıl, B.Z., \& Karabulut, A. N. (2014). Hane Halkının Süpermarket Alısverişlerindeki İçecek Ürünleri Tercihlerine Etki Eden Faktörlerin Araştırılması. Uluslararası Sosyal Araştırmalar Dergisi, 7 (29). www.sosyalarastirmalar.com Issn: 1307-9581

\section{Appendices}

N/A 